\title{
KEGIATAN SANGGAR SASTRA RUMAH PUISI TAUFIQ ISMAIL DALAM MENDUKUNG PERILAKU MENULIS
}

(Survei Pelatihan Menulis Karya Sastra Rumah Puisi Taufiq Ismail di Padang panjang)

\author{
Riska Fatma ${ }^{1}$,Ninis Agustini Damayani ${ }^{2}$, Agus Rusmana ${ }^{3}$ \\ ${ }^{1}$ Program Magister Ilmu Perpustakaan Universitas Indonesia, ${ }^{2,3}$ Program Studi Ilmu \\ Perpustakaan Universitas Padjadjaran \\ 1riskafatma22@yahoo.com, 2ninis_agustini@yahoo.com \\ 33gus.rusmana@unpad.ac.id
}

\begin{abstract}
This research purpose is to explain "Sanggar Sastra" activities at Rumah Puisi Taufiq Ismail in order to support behavior of writing literature among students, especially in Padang Panjang and Bukittinggi, West Sumatera. The method used is survey. Respondents in this research are twenty five senior high school students in Padang Panjang whom participate to "Sanggar Sastra" for a month. This research shows that an internal factor such as; members interest and external factors; sanggar sastra's teachers contributed to support behavior of writing literature among students. While the external factor such as the facilitation of "sanggar sastra" not directly give an contributed to support behavior of writing literature among students.
\end{abstract}

Keywords: Sanggar sastra, rumah puisi, behavior of writing.

ABSTRAK - Penelitian ini bertujuan untuk menggambarkan aktivitas "Sanggar Sastra" di Rumah Puisi Taufiq Ismail dalam mendukung perilaku menulis di kalangan pelajar, Padang panjang dan Bukittinggi, Sumatera Barat. Metode yang digunakan ialah survey. Responden dalam penelitian ini ialah 25 Sekolah Menangah Atas (SMA) di Padang Panjang yang berpartisipasi di "Sanggar Sastra" setiap bulannya. Penelitian ini menunjukkan bahawa faktor internal diantaranya; ketertarikan angora dan faktor eksternal; pengajar Sanggar Sastra yang berkontribusi mendukung prilaku menulis diantara pelajar. Sedangkan faktor eksternal yakni fasilitas Sanggar Sastra tidak berkontribusi dalam memberikan dukungan prilaku menulis diantara pelajar.

Kata kunci: Sanggar Sastra, rumah puisi, perilaku menulis.

\section{PENDAHULUAN}

Menulis merupakan suatu proses kreatif memindahkan gagasan ke dalam lambanglambang tulisan. Artinya adalah adanya tujuan atau maksud tertentu yang hendak dicapai dan adanya gagasan atau sesuatu yang hendak dikomunikasikan (Semi, 2007). Ketertarikan seseorang terhadap menulis tergantung dari minat yang dimilikinya. Seseorang tidak akan menghasilkan sebuah tulisan jika dia tidak memilki minat menulis dan kemauan yang kuat untuk menghasilkan karya nyata.

Dahulu banyak sekali penulis terkenal khususnya yang berasal dari Sumatera Barat menerbitkan karya-karya indah mereka. Deretan nama besar satrawan Minang itu, di antaranya Taufiq Ismail, Abdoel Moeis, Asrul Sani, Rivai Apin, Marah Rusli, Hamka, Sutan Takdir Alisyahbana, dan beberapa nama lainnya. Ambil saja salah satu contoh karya Hamka yaitu “Tenggelamnya Kapal Van Der Wijck" yang menarik perhatian belakangan ini. Karya tersebut merupakan hasil tulisannya yang pada dasarnya merupakan kisah nyata. Hamka mengabadikan kisah tersebut dalam novel dan mengemas ceritanya dengan kesusastraan yang indah. 
Namun seiring perkembangan masa dan waktu, kini sudah jarang terdengar nama-nama penulis yang menghasilkan karya terbaiknya.

Menurut Taufiq Ismail, "bukan faktor turunnya jumlah sastrawan Minang yang mewarnai khazanah kesusastraan Indonesia modern, namun kepentingan yang lebih besar dari itu adalah turunnya minat membaca dan menulis di kalangan generasi muda. Tidak hanya di Sumatera Barat namun meluas ke seluruh Tanah Air. Dampak dari turunnya minat membaca dan menulis menyebabkan minusnya karya sastra berbobot yang lahir di Tanah Air" (Kompasiana, 2014). Hal tersebut dikarenakan semakin berkurangnya minat membaca dan menulis di kalangan generasi muda yang semakin hari semakin termakan oleh perkembangan zaman. Anak muda saat ini lebih senang menghabiskan waktunya untuk pergi ke mall dan sekedar menggosip atau nongkrong bersama teman-teman lainnya dibandingkan pergi ke perpustakaan atau taman bacaan untuk membaca.

Kegiatan membaca dan menulis ibarat dua sisi mata uang yang tidak dapat dipisahkan. Seseorang tidak akan bisa menulis kalau tidak membaca terlebih dahulu. Dengan membaca, banyak atau sedikit, akan timbul rasa kagum terhadap tulisan yang kita baca. Pengetahuan baru banyak ditemui dan membuat kita banyak berfikir, yang nantinya bisa dijadikan referensi untuk berkarya tulis. Tentu saja kurangnya budaya membaca sangat mempengaruhi budaya menulis.

Kebiasaan membaca sejalan dengan kegiatan menulis. Jika kebiasaan membaca sudah ditanamkan, maka kebiasaan membaca secara otomatis akan menimbulkan keinginan untuk perlu mengkomunikasikan gagasan-gagasannya dalam bentuk yang permanen yaitu tulisan daripada bentuk tuturan atau ujaran. Untuk mengembangkan kemampuan menulis, seseorang perlu melakukan latihan menulis tersebut menjadi sebuah karya nyata. Banyak sumber informasi yang bisa didapatkan untuk menjadi referensi dalam membaca dan menulis seperti di perpustakaan atau taman baca. Namun masih banyak yang menganggap perpustakaan merupakan bangunan yang hanya menyimpan segudang buku saja.

Selama ini ketika mendengarkan kata "perpustakaan" bayangan kita masih tertuju pada sebuah ruangan yang berisi sekumpulan buku yang ditata di dalam rak. Padahal gambaran perpustakaan tidaklah sesempit itu. Perpustakaan bisa dihadirkan dimana saja. Pada dasarnya fungsi perpustakaan tidak sebatas fasilitas baca, tetapi juga sebagai wahana rekreasi. Di dalam perpustakaan terdapat juga wahana imajinasi rekreasi yang tidak akan kita dapatkan di tempat wisata manapun. Perpustakaan mempunyai peran yang strategis dalam meningkatkan kualitas intelektual warga masyarakat (Mursyid, 2015 ).

Pertumbuhan pesat perpustakaan, taman bacaan, rumah pintar, serta mobil pintar, hendaknya bermuara pada pengembangan sarana membaca dan belajar. Di era informasi saat sekarang, masyarakat dituntut untuk melek informasi dimana masyarakat dapat belajar sepanjang masa artinya bagaimana manusia itu bisa bertahan hidup karena mempunyai seperangkat keterampilan pemecah masalah 
dengan menggunakan sumber informasi yang ada. Proses pembelajaran harus dimulai dari sejak dini. Salah satu wadah yang bisa dijadikan tempat belajar dan sumber informasi bagi pelajar saat ini agar menjadi seseorang yang literer adalah perpustakaan ataupun taman baca yang bisa meningkatkan kegemaran membaca dan menulis.

Salah satu tempat belajar yang dapat dimanfaatkan khususnya yang ada di Padang Panjang, Sumatera Barat adalah Rumah Puisi Taufiq Ismail. Rumah Puisi Taufiq Ismail merupakan sebuah rumah baca yang menyimpan ribuan buku karya- karya sastrawan legendaris Indonesia. Rumah tersebut adalah warisan kesenian yang ditinggalkan oleh sang maestro, Taufiq Ismail. Dibangun pada tanggal 19 Desember 2008, di kota Padang Panjang yang berjarak lebih kurang $80 \mathrm{KM}$ dari ibu kota Sumatera Barat, Padang. Rumah Puisi Taufiq Ismail merupakan satu-satunya rumah bacaan yang dikemas dengan konsep modern, lengkap dengan fasilitas penunjang perpustakaan, kegiatan sanggar sastra, tempat pelatihan guru Bahasa dan Sastra Indonesia dan tempat berkumpulnya sastrawan Indonesia. Koleksi yang dimiliki adalah berbagai hasil karya sastra milik pribadi dari Taufiq Ismail. Namun ada juga beberapa koleksi umum yang berupa pemberian atau hadiah dan pembelian.

Nama Rumah Puisi tidak hanya serta merta bahwa kegiatannya hanya berkaitan dengan persajakan saja. Tetapi merangkum seluruh aktivitas yang bersangkutan dengan literatur dan literasi, karya sastra, pembacaan dan latihan penulisannya. Sangat menarik melihat kesuksesan
Taufiq Ismail dalam mengembangkan ilmu yang telah diperolehnya dengan mendirikan sebuah pusat informasi dan pembelajaran yang dapat dimanfaatkan oleh masyarakat. Melalui kebiasaannya membaca dan menulis, ia dapat menghasilkan berbagai karya sastra yang kini sosoknya telah dikenal semua orang. Nilai tambah dari Rumah Puisi Taufiq Ismail ini adalah dengan adanya keindahan panorama yang ada disekelilingnya membuat Rumah Puisi ini begitu menawan dan memukau karena terletak di antara kaki Gunung Singgalang dan Gunung Merapi. Selain itu terdapat berbagai tulisan sastra yang dipajang di halaman rumah tersebut. Hingga masuk ke dalam ruangan pun, orang-orang masih dimanjakan dengan keindahan tulisan-tulisan sastra yang terpajang di sekeliling dinding ruangan seperti melihat pameran karya sastra yang begitu indah.

Rumah Puisi Taufiq Ismail ini didirikan dengan tujuan untuk meningkatkan minat membaca dan menulis anak bangsa terutama didaerah kecil seperti Padang Panjang di Sumatera Barat. Dengan kehadiran Rumah Puisi Taufiq Ismail diharapkan bisa menjadi "trigger" yang mampu untuk menarik kembali perhatian masyarakat khususnya kalangan pelajar dalam menumbuhkan kecintaan membaca dan menulis terhadap hasil karya sastra di Indonesia khususnya di Sumatera Barat. Menurut Taufiq Ismail, "kecintaan membaca karya sastra merupakan awal kecintaan seseorang untuk membaca buku-buku lainnya. Hal itu bisa menambah wawasan dalam berbagai bidang kehidupan. Jika seseorang sudah demikian gandrung membaca buku maka pada sisi yang 
lain ia akan segera melirik dunia tulis-menulis untuk mengekspresikan hasil bacaannya," ujarnya (Kompasiana, 2014).

Berbagai upaya yang dilakukan dalam meningkatkan budaya membaca dan menulis hendaknya mampu untuk memberikan dorongan kepada seseorang agar dapat menjadikan kegiatan tersebut sebagai kebiasaan yang menyenangkan. Rumah Puisi Taufiq Ismail berupaya menyajikan koleksi-koleksi yang menarik khususnya di bidang karya sastra dan menyediakan fasilitas yang sangat nyaman bagi para pengunjung sehingga tempat untuk membaca dan menulis menjadi sangat menarik dan menyenangkan.

Senada dengan hal itu, menurut Rahmanto, "manfaat pengajaran sastra dalam dunia pendidikan adalah membantu siswa dalam empat aspek yaitu membantu meningkatkan keterampilan berbahasa, meningkatkan pengetahuan budaya, mengembangkan cipta dan rasa, dan menunjang pembentukan watak atau karakter" (Rahmanto, 1996). Sebab, karya sastra memiliki fungsi sebagai media etika (akhlak/moral), estetika (kepekaan terhadap seni dan keindahan) dan dialektika (pendidikan). Jika dipahami lebih mendalam karya sastra dapat menghasilkan ide-ide kreatif serta pemikiran baru yang dapat disalurkan melalui tulisan. Untuk menumbuhkan kecintaan pada membaca dan menulis, bisa dimulai dengan mencintai dan mempelajari bidang karya sastra.

Salah satu yang menarik dari Rumah Puisi Taufiq Ismail adalah disediakannya sebuah sanggar sastra. Sanggar sastra ini merupakan salah satu bentuk layanan yang disediakan oleh Rumah Puisi Taufiq Ismail. Dengan tujuan sebagai wadah pembelajaran bagi pelajar dalam meningkatkan motivasi dalam hal membaca dan menulis. Selain itu, mereka juga dapat mengeksplor kemampuan diri menjadi generasi yang memiliki daya juang yang tinggi dalam meningkatkan taraf kehidupan berkualitas di masa yang akan datang.

Sanggar sastra tersebut merupakan nama dari kegiatan sanggar membaca dan menulis yang dirancang oleh Taufiq Ismail dan ditujukan khusus bagi pelajar untuk memberikan pelatihan penulisan seluruh karya sastra baik cerpen, novel, puisi, esai dan sastra lainnya. Sanggar ini memiliki beberapa pengajar yang terdiri dari guru, sastrawan dan seniman. Anggota sanggar sudah memiliki anggota tetap namun tidak tertutup kemungkinan akan bertambah setiap minggunya karena jumlahnya tidak dibatasi. Anggota dari sanggar sastra ini adalah pelajar yang berasal dari utusan beberapa sekolah yang berada di sekitar Rumah Puisi Taufiq Ismail dan mereka yang memiliki minat menulis di bidang karya sastra serta ingin mendalami pengetahuan mengenai karya sastra.

Tujuan dari sanggar ini adalah untuk meningkatkan budaya membaca dan kemampuan menulis pelajar terhadap hasil karya sastra. Agar pelajar dapat menuangkan hasil pemikirannya, maka sanggar sastra ini dapat menjadi tempat belajar bagi para pelajar yang sebelumnya jarang menulis ataupun kerepotan dalam menulis khususnya karya sastra untuk menambah wawasan dan kemampuannya dalam menulis. Sorotan utama dalam penelitian ini adalah kegiatan pelatihan penulisan atau sangga sastra yang ada di Rumah Puisi Taufiq Ismail. 
Sanggar sastra memiliki keistimewaan dimana sistem yang digunakan dalam pelatihan berbeda dengan lembaga formal maupun informal lainnya. Bedanya adalah tidak ada aturan yang baku untuk mengikuti kegiatan ini. Sanggar sastra tidak menggunakan kurikulum, tidak ada ujian, tidak ada hukuman dan kegiatan pelatihan menulis ini tidak memungut biaya sepersenpun. Dengan adanya sanggar sastra ini diharapkan bisa memunculkan kembali semangat membaca dan menulis di kalangan pelajar. Khususnya dalam menumbuhkan kecintaan terhadap karya sastra. Berdasarkan paparan di atas, penelitian ini memiliki tujuan sebagai berikut:

1. Untuk menjelaskan peranan minat siswa pada sanggar sastra di Rumah Puisi Taufiq Ismail dalam mendukung perilaku menulis karya sastra di kalangan pelajar

2. Untuk menjelaskan peranan guru pada sanggar sastra di Rumah Puisi Taufiq Ismail dalam mendukung perilaku menulis karya sastra di kalangan pelajar

3. Untuk menjelaskan peranan fasilitas pada sanggar sastra di Rumah Puisi Taufiq Ismail dalam mendukung menulis karya sastra di kalangan pelajar.

\section{TINJAUAN PUSTAKA}

Dalam menulis adanya tujuan atau maksud tertentu yang hendak dicapai dan adanya gagasan atau sesuatu yang hendak dikomunikasikan (Semi, 2007). Beberapa penulis terkenal dari Sumatera Barat terkenal atas karya-karya indah mereka. Salah satunya Taufik Ismail. Menurutnya, "bukan faktor turunnya jumlah sastrawan Minang yang mewarnai khazanah kesusastraan Indonesia

modern, namun kepentingan yang lebih besar dari itu adalah turunnya minat membaca dan menulis di kalangan generasi muda [...]" (Kompasiana, 2014).

Untuk menghadapi masalah ini, perpustakaan dapat menjadi pendukung utama dalam menumbuhkan membaca dan menulis. Moh. Mursyid menyatakan, bahwa perpustakaan bisa dihadirkan dimana saja. Pada dasarnya fungsi perpustakaan tidak sebatas fasilitas baca, tetapi juga sebagai wahana rekreasi. Di dalam perpustakaan terdapat juga wahana imajinasi rekreasi yang tidak akan kita dapatkan di tempat wisata manapun. Perpustakaan mempunyai peran yang strategis dalam meningkatkan kualitas intelektual warga masyarakat (Mursyid, $2015)$.

Salah satu tempat belajar yang dapat dimanfaatkan khususnya yang ada di Padang Panjang, Sumatera Barat adalah Rumah Puisi Taufiq Ismail. Rumah Puisi Taufiq Ismail merupakan sebuah rumah baca yang menyimpan ribuan buku karya- karya sastrawan legendaris Indonesia. Salah satu layanannya bernama Sanggar Sastra, yang menjadi wadah pembelajaran bagi pelajar. Sanggar Sastra menjadi jalan bagi pelajar dalam meningkatkan motivasi membaca dan menulis melalui dunia sastra. Rahmanto menjelaskan alasannya bahwa melalui sastra, "[..]membantu siswa dalam empat aspek yaitu membantu meningkatkan keterampilan berbahasa, meningkatkan pengetahuan budaya, mengembangkan cipta dan rasa, dan menunjang pembentukan watak atau karakter" (Rahmanto, 1996). Karya sasta 
sebagai cara untuk menumbuhkan kecintaan pada membaca dan menulis. Karya sastra berperan sebagai media etika (akhlak/moral), estetika (kepekaan terhadap seni dan keindahan) dan dialektika (pendidikan). yang dapat menghasilkan ide-ide kreatif serta pemikiran baru yang dapat disalurkan melalui tulisan.

\section{METODE PENELITIAN}

Metode yang digunakan dalam penelitian ini adalah survey dengan mengambil sampel dari suatu populasi dan menggunakan angket sebagai alat pengumpul data (Singarimbun \& Effendi, 1989). Metode yang digunakan dalam penelitian ini adalah metode kuantitatif. Metode penelitian kuantitatif merupakan metode penelitian yang diartikan sebagai metode penelitian yang berlandaskan pada filsafat positivisme, digunakan untuk meneliti pada populasi atau sampel tertentu (Sugiyono, 2009 ).

Penelitian survey bertujuan untuk mengungkapkan gambaran umum yang berlaku pada sejumlah variasi situasi dan kondisi. Metode ini digunakan untuk mendeskripsikan dan menjelaskan berbagai karakteristik, persepsi, opini, sikap dan perilaku dari sampel responden yang merupakan representasi dari populasi penelitian. Umumnya pengertian survey dibatasi pada penelitian yang datanya dikumpulkan dari sampel atas populasi untuk mewakili seluruh populasi. Pada penelitian ini yang menjadi populasi adalah seluruh anggota sanggar sastra Rumah Puisi Taufiq Ismail yang berjumlah 25 orang. Anggota yang diteliti merupakan anggota yang sedang mengikuti kegiatan sanggar sastra selama satu bulan yaitu pada tanggal 20 Februari 2015 - 13 Maret 2015.

Sebagian besar anggota adalah yang baru masuk untuk mengikuti sanggar sastra dan beberapa lainnya telah mengikuti sanggar sastra sebelumnya. Anggota sanggar sastra ini adalah mereka yang memiliki hobi menulis dan yang ingin mendalami pengetahuan mengenai menulis karya sastra. Populasi merupakan wilayah generalisasi yang terdiri atas: obyek/subyek yang mempunyai kualitas dan karakteristik tertentu yang ditetapkan oleh penelitiuntuk dipelajari dan kemudian ditarik kesimpulannya (Sugiyono, 2009 ). Sampel yang digunakan adalah sensus dimana semua anggota populasi dijadikan responden karena jumlah populasi dapat terjangkau oleh peneliti.

\section{HASIL DAN PEMBAHASAN}

Adapun responden dari penelitian ini (72\%) adalah perempuan dan (28\%) adalah laki-laki. Sebagian besar dari responden merupakan siswa SMA kelas dua SMA yang berusia 16-18 tahun. Data penelitian yang menganalisis peranan sanggar sastra di Rumah Puisi Taufiq Ismail terhadap perilaku menulis ini diantaranya meliputi:
a. Minat anggota sanggar sastra
b. Guru sanggar sastra
c. Fasilitas sanggar sastra
d. Perilaku menulis

Minat anggota sanggar sastra dapat dijabarkan ke dalam 6 (enam) variabel. Variabel pertama, menyatakan $72 \%$ anggota sanggar 
senang terhadap kegiatan menulis. Kedua, 96\% anggota sanggar tertarik terhadap sanggar sastra. Ketiga, $48 \%$ anggota menyatakan intensitas keanggotannya cukup baik. Ke-4, 64\% anggota sanggar cukup aktif bertanya kepada guru. Ke-5, 80\% anggota sanggar cukup baik dalam pengerjaan tugas. Ke-6 100\% anggota sanggar merasakan manfaat terhadap sanggar sastra. Ini digambarkan dalam tabel di bawah ini.

Tabel 1. Data minat anggota sanggar sastra

\begin{tabular}{|c|}
\hline A. Minat Anggota Sanggar sastra \\
\hline $\begin{array}{l}\text { 1. (72\%) Anggota sanggar sastra senang } \\
\text { terhadap kegiatan menulis. }\end{array}$ \\
\hline $\begin{array}{l}\text { 2. (96\%) Ketertarikan anggota terhadap } \\
\text { sanggar sastra sangat besar. }\end{array}$ \\
\hline $\begin{array}{l}\text { 3. (48\%) Intensitas mengikuti sanggar } \\
\text { sastra cukup baik. }\end{array}$ \\
\hline $\begin{array}{l}\text { 4. (64\%) Anggota sanggar sastra cukup } \\
\text { aktif bertanya kepada guru. }\end{array}$ \\
\hline $\begin{array}{l}\text { 5. (80\%) Anggota sanggar sastra cukup } \\
\text { baik dalam pengerjaan tugas. }\end{array}$ \\
\hline $\begin{array}{llll}6 . \quad(100 \%) & \text { Anggota } & \text { sanggar sastra } \\
\text { merasakan } & \text { manfaat } & \text { yang } & \text { banyak } \\
\text { terhadap sanggar sastra. } & & \end{array}$ \\
\hline
\end{tabular}

Sumber: Analisis hasil penelitian

Data mengenai guru sanggar sastra dijabarkan dalam 4 (empat) variabel. Pertama, 92\% anggota sanggar menyatakan bahwa guru memiliki pengetahuan luas dan penguasaan materi. Kedua, 96\% anggota menyatakan guru memiliki sikap baik selama proses belajar. Ketiga, 96\% anggota sanggar menyatakan bahwa gaya guru menyenangkan. Ke-4, 64\% anggota sanggar cukup aktif bertanya pada guru. Ini digambarkan dalam tabel di bawah ini.

Tabel 2. Data guru sanggar sastra

\section{B. Guru sanggar sastra}

1. (92\%) Guru berpengetahuan luas dan menguasai materi.

2. (96\%) Sikap guru baik dalam proses belajar.

3. $(96 \%)$ Gaya guru menyenangkan.

4. (64\%) Anggota sanggar sastra cukup aktif bertanya kepada guru.

Sumber: Analisis hasil penelitian

Data mengenai fasilitas sanggar sastra dijabarkan dalam 4 (empat) variabel. Pertama, $56 \%$ anggota sanggar menyatakan fasilitas yang diberikan sanggar cukup memadai dan lengkap. Kedua, 52\% anggota sanggar menyatakan penggunaan koleksi cukup baik. Ketiga, 88\% anggota menyatakan tempat dan suasana sanggar dirasakan nyaman. Ke-4, anggota sanggar cukup aktif bertanya pada guru.

Tabel 3. Data fasilitas sanggar sastra

\section{Fasilitas Sanggar sastra}

1. (56\%) Fasilitas yang diberikan cukup

2. (52\%) Penggunaan koleksi cukup baik

3. (88\%) Tempat dan suasana yang dirasakan nyaman

4. (64\%) anggota sanggar sastra cukup aktif bertanya kepada guru

Sumber: Analisis hasil penelitian

Data perilaku menulis dijabarkan dalam 3 (tiga) variabel. pertama, 52\% anggota sanggar dalam frekuensi menulis cukup baik yaitu 2-3 kali 
seminggu. Kedua, $48 \%$ anggota sanggar menyatakan bahwa bentuk tulisan yang banyak dibuat ialah puisi dan cerpen. Ketiga, $40 \%$ ratarata anggota sanggar telah membuat 2 genre tulisan.

Tabel 4. Data perilaku menulis

\section{Perilaku Menulis}

1. $(52 \%)$ Frekuensi menulis anggota sanggar sastra cukup baik yaitu 2-3 kali seminggu

2. (48\%) bentuk tulisan yang paling

banyak dibuat adalah puisi dan cerpen

3. (40\%) Rata-rata anggota sanggar sastra telah membuat 2 genre

Sumber: Analisis hasil penelitian

\section{SIMPULAN}

Berdasarkan hasil penelitian dan pembahasan mengenai peranan sanggar sastra terhadap perilaku menulis karya sastra di kalangan pelajar (khususnya di Padang Panjang, Sumatera Barat), maka kesimpulan yang dapat diambil adalah sebagai berikut :

1. Minat anggota sanggar sastra berperan dalam mendukung perilaku menulis karya sastranya. Minat anggota yang berupa kesenangan, ketertarikan, kecenderungan berusaha lebih aktif, intensitas mengikuti sanggar sastra dan kesadaran akan manfaat pada sanggar sastra di Rumah Puisi Taufiq Ismail telah mendorong anggota sanggar sastra untuk lebih bersemangat dan giat untuk mengikuti kegiatan sanggar sastra. Minat anggota sanggar sastra bagus dalam mendukung mereka meningkatkan kemampuan dan motivasi dalam menulis karya sastra. Semakin besar minat yang terdapat dalam diri anggota terhadap menulis maka semakin besar keinginan anggota untuk menulis karya sastra

2. Guru sanggar sastra berperan dalam mendukung perilaku menulis karya sastra di kalangan pelajar. Faktor eksternal yang berupa penguasaan materi guru yang baik dan berpengetahuan luas dalam mengajar, sikap guru yang ramah dan terbuka dalam mengajar, gaya guru yang menyenangkan dan interaktif dalam mengajar, hubungan yang akrab antara guru dengan anggota sanggar sastra dalam mengajar, metode yang variatif dan tidak membosankan dan materi yang cukup mudah dipahami dan cukup jelas dapat membuat anggota sanggar sastra lebih termotivasi dan memperkuat diri mereka dalam belajar menulis karya sastra. Guru berperan baik dalam mendukung aktivitas menulis anggota dari yang sebelumnya jarang menulis menjadi lebih sering untuk menulis. Artinya guru dapat memberikan dorongan kepada anggota sanggar sastra dengan kemampuan yang dimilikinya untuk meningkatkan motivasi menulis dan membuat anggota semakin giat 
serta semangat dalam kegiatan menulis karya sastra

3. Fasilitas pada sanggar sastra tidak secara langsung berperan terhadap perilaku menulis karya sastra di kalangan pelajar. Tanpa adanya fasilitas, anggota sanggar sastra memang sudah memiliki kesenangan dengan kegiatan menulis, sehingga fasilitas berupa koleksi hanya menjadi faktor pendukung bagi mereka dalam menulis berbagai genre tulisan. Namun, fasilitas sanggar sastra yang berupa suasana dan tempat yang nyaman untuk belajar, waktu yang cukup disediakan, dapat membuat anggota sanggar sastra untuk belajar dengan baik dan mendorong mereka untuk mau datang ke Rumah Puisi Taufiq Ismail mengikuti kegiatan sanggar sastra.

4. Dari simpulan di atas dapat diketahui bahwa sanggar sastra dapat menjadi kegiatan yang positif dan bagus untuk diterapkan bagi kalangan pelajar yang memiliki minat menulis sehingga dapat menjaga keberlangsungan aktivitas menulis, memperkuat mereka dalam menulis karya sastra dan meningkatkan motivasi untuk menghasilkan karya yang bermanfaat sepanjang hayatnya.

Dari simpulan di atas dapat diketahui bahwa sanggar sastra dapat menjadi kegiatan yang positif dan bagus untuk diterapkan bagi kalangan pelajar yang memiliki minat menulis sehingga dapat menjaga keberlangsungan aktivitas menulis, memperkuat mereka dalam menulis karya sastra dan meningkatkan motivasi untuk menghasilkan karya yang bermanfaat sepanjang hayatnya.

\section{DAFTAR PUSTAKA}

Kompasiana. (2014, september 23 ). Retrieved from Wisata Sastra di Rumah Taufik Ismail: http://wisata.kompasiana.com/jalanjalan/2011/10/31/yuk-wisata-sastra-dirumah-puisi-taufiq-ismail-408383.html

Mursyid, M. (2015 ). Pustakawan \& Media Massa. Yogyakarta: Lembaga Ladang Kita.

Rahmanto, B. (1996). Metode Pengajaran Sastra. Yogyakarta: Kanisius.

Semi, A. (2007). Dasar-dasar Keterampilan Menulis. Bandung : Angkasa.

Singarimbun, \& Effendi, S. (1989). Metode Penelitian Survei. Jakarta : LP3S.

Sugiyono. (2009). Metode Penelitian Kuantitatif Kualitatif dan R\& D. Bandung : Alfabeta. 
